

\section{Gearbox Reliability Collaborative: Gearbox Inspection Metadata}

Technical Report NREL/TP-500-49133

September 2010

Kristin Munch and Mark McDade

Prepared under Task No(s). WE10.1132

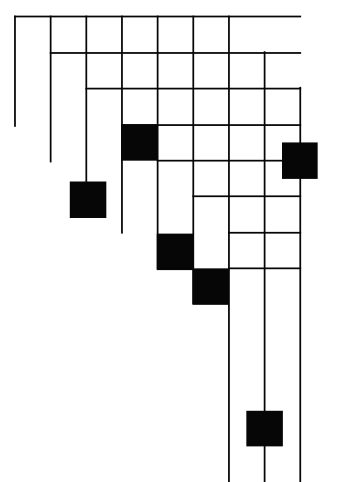

National Renewable Energy Laboratory

1617 Cole Boulevard, Golden, Colorado 80401-3393

303-275-3000 • www.nrel.gov

NREL is a national laboratory of the U.S. Department of Energy

Office of Energy Efficiency and Renewable Energy

Operated by the Alliance for Sustainable Energy, LLC

Contract No. DE-AC36-08-GO28308 


\section{NOTICE}

This report was prepared as an account of work sponsored by an agency of the United States government. Neither the United States government nor any agency thereof, nor any of their employees, makes any warranty, express or implied, or assumes any legal liability or responsibility for the accuracy, completeness, or usefulness of any information, apparatus, product, or process disclosed, or represents that its use would not infringe privately owned rights. Reference herein to any specific commercial product, process, or service by trade name, trademark, manufacturer, or otherwise does not necessarily constitute or imply its endorsement, recommendation, or favoring by the United States government or any agency thereof. The views and opinions of authors expressed herein do not necessarily state or reflect those of the United States government or any agency thereof.

Available electronically at http://www.osti.gov/bridge

Available for a processing fee to U.S. Department of Energy and its contractors, in paper, from:

U.S. Department of Energy

Office of Scientific and Technical Information

P.O. Box 62

Oak Ridge, TN 37831-0062

phone: 865.576 .8401

fax: 865.576 .5728

email: mailto:reports@adonis.osti.gov

Available for sale to the public, in paper, from:

U.S. Department of Commerce

National Technical Information Service

5285 Port Royal Road

Springfield, VA 22161

phone: 800.553.6847

fax: 703.605.6900

email: orders@ntis.fedworld.gov

online ordering: http://www.ntis.gov/ordering.htm 


\section{NREL/NWTC Gearbox Reliability Collaborative Database GearFacts Software}

The Gearbox Reliability Collaborative (GRC) is a U.S. Department of Energy (DOE)/National Renewable Energy Laboratory (NREL) project to identify and understand premature failure of components in wind turbine gearboxes. These failures are a leading source of unplanned expense in the operation of commercial wind turbines. Analysis and root cause correction of these failures is critical to enhancing the commercial viability of wind power as a sustainable energy source. A key component of the overall GRC effort is the creation of a database of gearbox failure history. To this end, NREL has developed a software application called GearFacts that will be distributed to Database Collaborative participants to capture failure information when gearboxes are rebuilt. This publication names and describes each field used in GearFacts and can be used as a reference to the software's design.

GearFacts software will be used at the time of a rebuild to guide rebuilders in defining and entering gear and bearing failure details including a photographic record of failure mechanisms. The owner of the gearbox will be able to use any information they have entered to maintain their own rebuild records and to produce reports on their fleet of gearboxes. The research community will be able to use aggregated data from the database to develop statistics on gearbox failure mechanisms, failure timing and, in some cases, costs. The aggregated reporting system will be secured and 'sanitized' to remove identifying data which might convey ownership (or other proprietary) information. In addition, participants in the collaborative will be able to access and utilize data from the testing and analysis portions of the GRC.

For more information about the GRC and its background and proposed research agenda, please see "Improving Wind Turbine Gearbox Reliability" (NREL conference paper CP-500-41548), May 2007. You can access this paper at: http://www.nrel.gov/docs/fy07osti/41548.pdf. 


\section{MetaData Collection Elements}

The list below describes the metadata elements associated with a gearbox inspection in the Gearbox Reliability Collaborative.

\begin{tabular}{|l|l|}
\hline Field name & \\
\hline Rebuilder name & Field description \\
\hline rebuild site & Group or individual rebuilding gearbox. \\
\hline gearbox owner & Where rebuilt. \\
\hline gearbox responsible contact & Owner contact. \\
\hline $\begin{array}{l}\text { Gearbox responsible contact } \\
\text { phone }\end{array}$ & \\
\hline Wind site name & \\
\hline Wind site address 1 & \\
\hline Wind site address 2 & \\
\hline wind site city & \\
\hline wind site state & \\
\hline Wind site zip & \\
\hline Wind site country & \\
\hline Site turbulence intensity & Using standard nomenclature as available. \\
\hline Site capacity factor & Actual generation over potential generation. \\
\hline Operating power & Turbine rated output. \\
\hline Gearbox install date & The date the gearbox was installed on this turbine. \\
\hline Gearbox startup date & The date this gearbox first went into operation. \\
\hline Gearbox shutdown date & The date this gearbox was shutdown due to fault. \\
\hline Gearbox removal date & The date this gearbox was removed from the turbine. \\
\hline Cumulative run time hours & $\begin{array}{l}\text { The total amount of time this gearbox has run since last } \\
\text { rebuild. }\end{array}$ \\
\hline Turbine OK hours & SCADA data which may be unavailable during rebuild. \\
\hline Production since new or rebuilt & $\begin{array}{l}\text { Total production in kWh since new (or last rebuilt if not } \\
\text { new). }\end{array}$ \\
\hline Line loss stops & SCADA data which may be unavailable during rebuild. \\
\hline Emergency stops & SCADA data which may be unavailable during rebuild. \\
\hline Wind site comments & \\
\hline & \\
\hline Oil cooler installed & Is an oil cooler installed? \\
\hline Max online filter size & in microns \\
\hline Max offline filter size & in microns \\
\hline Sample collection point & Where on gearbox was oil taken? \\
\hline Sample collection date & The date the sample was collected, after the failure? \\
\hline Has dessicant breather & Is a dessicant breather installed? \\
\hline Lubricant comments & \\
\hline & \\
\hline Failure date & Date of the failure \\
\hline How discovered & Short description of how the failure was discovered. \\
\hline & \\
\hline
\end{tabular}




\begin{tabular}{|c|c|}
\hline Unusual conditions & \\
\hline SCADA data available & Is SCADA data available for this gearbox? \\
\hline SCADA data output format & If SCADA data is available, what is its format? \\
\hline Similar failed & $\begin{array}{l}\text { The number of similar gearboxes that have failed on this } \\
\text { site? }\end{array}$ \\
\hline Similar running & $\begin{array}{l}\text { The number of similar gearboxes that are running on this } \\
\text { site? }\end{array}$ \\
\hline Site terrain description & A short description of the terrain of this site. \\
\hline Terrain surrounding turbine & $\begin{array}{l}\text { A short description of the terrain around the turbine } \\
\text { where this gearbox was installed. }\end{array}$ \\
\hline Site climate & \begin{tabular}{|l} 
Desert, ocean, or inland. \\
\end{tabular} \\
\hline Inspection comments & \\
\hline Gearbox name & \\
\hline Manufacturer & \\
\hline Model & \\
\hline New or rebuilt? & When last installed. \\
\hline Rebuild location & If rebuilt, above - shop, tower, unknown? \\
\hline Power rating & \\
\hline Gear ratio & \\
\hline Serial number & \\
\hline$\{$ Image of the gearbox ID tag\} & \\
\hline Storage & $\begin{array}{l}\text { Please indicate whether the gearbox was stored indoors } \\
\text { or outdoors after removal from turbine. }\end{array}$ \\
\hline Mount & Number of mount points. \\
\hline Inspection date & \\
\hline Lead investigator & \\
\hline Assisting investigator & \\
\hline Attached images & $\begin{array}{l}\text { Images may be attached to any of the above areas and } \\
\text { are critical to the usefulness of an incident report. }\end{array}$ \\
\hline Enter data for lubricant: & \\
\hline Manufacturer & Manufacturer of the lubricant used in this gearbox. \\
\hline Type Grade & Type and grade of lubricant used in this gearbox. \\
\hline Last change date & The date the lubricant was last changed \\
\hline Lab analysis available & Is a lab analysis report available for this lubricant? \\
\hline Analysis frequency & How frequently was the lubricant analyzed? \\
\hline Lab used & The name of the lab that analyzed the lubricant. \\
\hline $\begin{array}{l}\text { Oil temperature control low set- } \\
\text { point }\end{array}$ & Fahrenheit/centigrade \\
\hline $\begin{array}{l}\text { Oil temperature control high set- } \\
\text { point }\end{array}$ & Fahrenheit/centigrade \\
\hline Enter for each gear: & \\
\hline Gear type & Helical/spur. \\
\hline Teeth & The number of teeth on this gear. \\
\hline Gear handedness & Left/right \\
\hline
\end{tabular}




\begin{tabular}{|l|l|}
\hline Outside diameter & The outer diameter of the gear. \\
\hline Face width & The face width of the teeth. \\
\hline Whole depth of teeth & \\
\hline Tooth thickness span & \\
\hline Tooth thickness top land & Comments concerning the inspection of this gear \\
\hline Gear comments & $\begin{array}{l}\text { Choose a classification category, and a sub- } \\
\text { classification. }\end{array}$ \\
\hline Failure classification & \\
\hline Enter for each bearing: & \\
\hline Bearing type & \\
\hline Bearing orientation & \\
\hline Bearing set orientation & Maker of this bearing. \\
\hline Make & Country of make of this bearing. \\
\hline Country & \\
\hline Inner race outside diameter & \\
\hline Inner race inside diameter & \\
\hline Outer race outside diameter & \\
\hline Outer race inside diameter & \\
\hline Width & \\
\hline Number of rollers & \\
\hline Roller profile & \\
\hline Roller diameter & Comments concerning the inspection of this bearing \\
\hline Roller length & \\
\hline Cage type & \\
\hline Cage material & \\
\hline Comments & \\
\hline Failure classification & \\
\hline
\end{tabular}




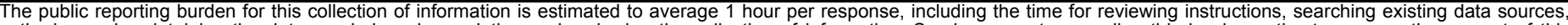

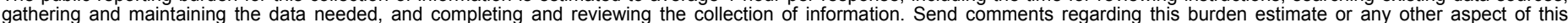

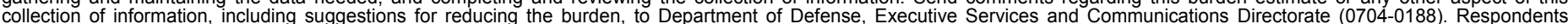

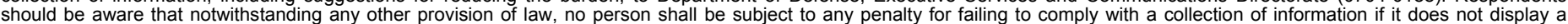

should be aware that notwithstanding

PLEASE DO NOT RETURN YOUR FORM TO THE ABOVE ORGANIZATION.

\begin{tabular}{l|l|l|l} 
1. REPORT DATE $(D D-M M-Y Y Y Y)$ & 2. REPORT TYPE & 3. DATES COVERED (FrOm - TO)
\end{tabular}

September 2010

4. TITLE AND SUBTITLE

Gearbox Reliability Collaborative: Gearbox Inspection Metadata 5a. CONTRACT NUMBER

DE-AC36-08-GO28308

5b. GRANT NUMBER

5c. PROGRAM ELEMENT NUMBER

5d. PROJECT NUMBER

NREL/TP-500-49133

5e. TASK NUMBER

WE10.1132

5f. WORK UNIT NUMBER
7. PERFORMING ORGANIZATION NAME(S) AND ADDRESS(ES)

National Renewable Energy Laboratory

1617 Cole Blvd.

Golden, CO 80401-3393

\section{PERFORMING ORGANIZATION REPORT NUMBER \\ NREL/TP-500-49133}

9. SPONSORING/MONITORING AGENCY NAME(S) AND ADDRESS(ES)

10. SPONSOR/MONITOR'S ACRONYM(S) NREL

11. SPONSORING/MONITORING AGENCY REPORT NUMBER

12. DISTRIBUTION AVAILABILITY STATEMENT

National Technical Information Service

U.S. Department of Commerce

5285 Port Royal Road

Springfield, VA 22161

13. SUPPLEMENTARY NOTES

14. ABSTRACT (Maximum 200 Words)

NREL has developed a software application called GearFacts that will be distributed to Database Collaborative participants to capture failure information when gearboxes are rebuilt. This publication names and describes each field used in GearFacts and can be used as a reference to the software's design.

15. SUBJECT TERMS

wind; gearboxes; GRC; database; failure analysis; failure history.

\begin{tabular}{|c|c|c|}
\hline $\begin{array}{l}\text { a. REPORT } \\
\text { Unclassified }\end{array}$ & $\begin{array}{l}\text { b. ABSTRACT } \\
\text { Unclassified }\end{array}$ & $\begin{array}{l}\text { c. THIS PAGE } \\
\text { Unclassified }\end{array}$ \\
\hline
\end{tabular}

\begin{tabular}{l|l|l}
$\begin{array}{l}\text { 17. LIMITATION } \\
\text { OF ABSTRACT }\end{array}$ & $\begin{array}{l}\text { 18. NUMBER } \\
\text { OF PAGES }\end{array}$ \\
UL &
\end{tabular}

19a. NAME OF RESPONSIBLE PERSON

19b. TELEPHONE NUMBER (Include area code) 